\title{
Imminent Linguicide Of Indigenous Language In South-West, Nigeria: Causes, Consequences And Cure.
}

\author{
ADERIBIGBE, Moronmubo Martina PhD \\ muboakinseli@gmail.com \\ $+2348033067952$ \\ DOI: $10.31364 / S C I R J / v 7 . i 10.2019 . P 1019704$ \\ http://dx.doi.org/10.31364/SCIRJ/v7.i10.2019.P1019704
}

\begin{abstract}
Linguicide, the death of a language, is a gradual process that starts with language corruption, graduates to abandonment, and ultimately results in ethnocide, the death of an ethnic group, because if a language dies, the owners of the language cease to exist. Indigenous language is the local language of a people, spoken by the indigenes of the region.

The importance of indigenous language cannot be over-emphasised. The ability to communicate clearly and effectively in one's indigenous language shapens one's personal identity as it strengthens such a person's bond to his ethnic group. Apart from this, good health, reduction of suicide and chronic diseases have been traced by many researchers to ability to communicate in their indigenous languages. It is also proven that the heart and soul is contacted with indigenous language. For instance, there was an undergraduate student of a South-Western state University in Nigeria who suddenly ran berserk without a cause and all efforts to calm him down proved abortive. An old man who witnessed the incidence suggested that his lineage praise (oríki) be chanted to him, this mysteriously calmed him down. If he did not understand the language of the oriki, it might not have had such effect on him.

Furthermore, indigenous language is the strongest and most reliable means of passing on cultural heritage and knowledge from generation to generation. It keeps people connected to culture and this strengthens feelings of pride and selfworth. Given the indigenous language is an important aspect of culture, and indigenous cultures are some of the strongest modes we have to live in harmony with the earth and each other, we cannot afford its loss.

Unfortunately, as important and useful as the indigenous language is, it is fast disappearing. People in the South-Western part of Nigeria, especially youths and children, no longer speak Yoruba and this will ultimately culminate in the demise of the language.

Many researchers in this part of Nigeria have suggested various laudable ways of curbing the menace of loss of indigenous language in seminars, conferences, and workshops but it seems as if their reports all end on the shelf without bringing it home to the notice of the stakeholders. Also, there have been little or no researches into the real causes of this menace, hence this research. The researcher sees that no permanent and effective cure could be proffered without first identifying the root cause and exposing the stakeholders to the unpalatable consequences of their acts in future. The effective cure could even be derived from the identification of the causes.
\end{abstract}

Key words: Linguicide, Language Corruption, Indigenous Language, South-West Nigeria

\section{INTRODUCTION}

Indigenous language is a precious gift of nature that is so useful and important not only for the sustenance of culture, but also for the development of the nation. According to Yglesias (2015), indigenous language is more than ordinary words. It is the means of expression that best communicates culture to the material world. It is an important cultural heritage that should not be treated with levity.

A language is said to be dying if it is no longer taught to the children of the community or at least to a large number of children. In these cases, the remaining fluent speakers of the language are generally older members of the community, and when they pass on, the language dies with them. Also, if a language is associated with lower social class, such language is endangered because parents will encourage their children to use the supposedly superior language in the society to distance themselves from the perceived lower class or primitive people, consequently, within one or two generations, the language can easily be lost.

The decline in the speaking of indigenous language is not peculiar to Nigeria. It is an issue of utmost concern all over the world. According to Glavin et al (2008), many indigenous peoples worldwide have stopped passing on their ancestral languages to the next generation, and have adopted the majority language as part of their acculturation into majority culture. In North America, since 1600, at least 52 Native American languages have disappeared. It is estimated that 6,809 "living" languages exist in the world today but $90 \%$ of them are spoken by fewer than 100,000 people. This means that about 6,100 languages are facing the risk of extinction.

Linguists in Nigeria are not left out. They are worried about the state of our indigenous languages in Nigeria. We are losing this precious skill, and it is somewhat affecting the socio-cultural development of the country. They insist that pragmatic 
efforts should be made to encourage the use of indigenous languages like Yoruba, Igbo, Hausa, Urhobo, Itsekiri among others. The linguists believe that promotion of indigenous languages will facilitate the fulfilment of nation development aspirations, arguing that most developed countries effectively use their indigenous languages to foster national growth.

As it is essential to the well-being and development of the nation, so it is to individual lives. Indigenous science and technology could be a good means of enhancing the development of the nation if it is promoted, but this cannot be done without the use of indigenous language which is being relegated and neglected due to many factors like urbanisation, colonialism, globalisation, to mention but few. If care is not taken, this may lead to the death of our indigenous languages. In Nigeria, especially in the South West, many parents forbid their children to speak Yoruba in their homes, even parents who do not have western education encourage their children to communicate in English language, it does not matter if they are grammatically correct or not. Schools punish pupils who speak Yoruba in schools thus discouraging them from using their indigenous language as a medium of communication. Everybody is turning his / her back to indigenous language, why?

This is the question this research intends to answer. Also the consequences of the neglect now as it is manifesting in the society will be brought to the fore as seen on the field and the possible cure will be postulated.

\section{PROBLEM STATEMENT}

In South-Western part of Nigeria, most youths and children cannot speak the indigenous language which is Yoruba language neither can they communicate effectively in English language. This is because they have been disengaged from their roots and there is no proper grounding or integration in English language. Consequently, most of them are baseless linguistically. Indigenous language is fast disappearing, and of course, the culture along with it, this is telling on the region and Nigeria as a whole.

\section{OBJECTIVES}

The research is set out to find out the causes of the waning use of indigenous language which is Yoruba language in the South-Western part of Nigeria. This also, we will bring to the fore the consequences of this on the ethnic group and on Nigeria as a whole. The study will also suggest, based on the findings on the causes, how this menace could be arrested before it escalates into the demise of the indigenous language.

\section{LITERATURE REVIEW}

As earlier mentioned, the issue of the diminishing use of indigenous language occupies the front burner in linguists' conferences, seminars and researches. On the world mother tongue day in 2007, Owolabi highlights some causes of lingucide, established the fact that if care is not taken promptly, Yoruba language may go into extinction. He also suggested ways of avoiding this. Babalola and Onanuga (2012) consider the athrophization of minority languages and suggest that folktales could be used in rescuing the dying language and culture, it should be encouraged among adults and children. They recommend that all hands must be on deck to do this onerous task: the government, parents, teachers, youths, scholars, educators, policy makers, and even children, everyone has a role to play to ensure the preservation of this cultural heritage.

In finding an answer to if truly the indigenous language can survive, Oshodi (2013) assesses the factors responsible for language endangerment of indigenous Nigerian languages using the UNESCO expert model designs specifically for measuring the endangerment level of any language. It investigates the endangerment of Arigidi language spoken in small communities in South West Nigeria. The study concludes that rescuing the already dying language will be a herculean task.

Furthermore, Balogun (2013) examines the low usage of Yoruba language among some selected secondary school students in Yorubaland. The result shows that many students from which the data was drawn found it extremely difficult to express themselves freely in Yoruba language, neither did they know the meaning of some proverbs, words and expressions given to them. The study therefore concludes that Yoruba language stands the risk of gradual extinction if urgent actions are not taken by stakeholders. Like Babalola and Onanuga (2012), he rests the task on the shoulders of government, parents, schools, policy makers, language planners, and other stakeholders.

A documentary linguist, Olaoye (2014) observes that the rich culture of greeting among the Yoruba is fast waning, he documents three Yoruba dialects, İjèbú, İjẹșà and İgbómìnà which he believes will make them accessible to the coming generation, thus saving them from gradual extinction.

Lastly, in 2016, Aladesote et al use feature extraction techniques to identify some possible causes of the extinction of Yoruba language. Using WEKA 3.7, the researchers extracted variables responsible for Yoruba language endangerment. The result shows that lack of commitment to indigenous language, habitat displacement, colonial legacy, devastating ferocious diseases and defective language planning are factors responsible for the menace. The study therefore recommends that parents should be committed to the use of Yoruba as a medium of communication at home since a Yoruba adage says ilé la ti ń késọó ròde(charity begins at home), and it should be one of the major requirements for admission into post primary level of education.

One fact is common to all these researches discussed above: Yoruba indigenous language has started its journey into oblivion, and there is an urgent need to steer its ship away from this fatal terminus.

\section{METHODOLOGY:}

The research was be carried out in the six $\{6\}$ states that make up the South-Western part of Nigeria where Yoruba is spoken predominantly. Questionnaire, which is the main research instrument, were administered in the capitals of these states. The capitals were selected because recent studies have shown that the decline in the use of Yoruba indigenous language is prevalent in urban areas, and the state capitals are considered as the most urban towns in the states. 
In each state, 120 parents (40 with high level of formal education (first degree to $\mathrm{PhD}$ holders), 40 with low level of formal education (School leaving certificate to Secondary school certificate holders), 40 with no formal education), 20 heads of schools (10 private schools, 10 public or government schools), and 20 youths. Also, children and market women were interviewed. In all, there were over 1,000 respondents from whom data were drawn.

\section{SUMMARY OF THE FINDINGS OF THE STUDY}

\section{PARENT DATA:}

\section{SOCIO DEMOGRAPHIC CHARACTERISTICS OF PARENT RESPONDENTS IN SOUTHWEST NIGERIA}

\section{A. AGE DISTRIBUTION OF PARENT RESPONDENTS IN SOUTHWEST NIGERIA.}

The age characteristics of parent respondents used in this study is presented in Table1 below.

From Table1, most parents (55.5percent) interviewed are within the age bracket of 26 and 45 years. This is followed by age bracket of 46 and 60years. The least group of the parents (4.8percent) are 60 years and above while the remaining 9.8 percent are within 18 and 25 years.

Table1: Age Characteristics of Parent Respondents in Southwest Nigeria.

\begin{tabular}{|l|c|c|}
\hline Age & Frequency & Percent \\
\hline $18-25$ YEARS & 65 & 9.8 \\
$26-45$ YEARS & 369 & 55.5 \\
$46-60$ YEARS & 199 & 29.9 \\
60 YEARS AND ABOVE & 32 & 4.8 \\
\hline Total & $\mathbf{6 6 5}$ & $\mathbf{1 0 0 . 0}$ \\
\hline
\end{tabular}

\section{B. EDUCATIONAL QUALIFICATION DISTRIBUTION OF PARENT DISTRIBUTION IN SOUTHWEST NIGERIA}

Table 2 and Figure 1 reveal the qualification of parent respondents. 87.8 percent of the parent respondents have high level of education while the remaining 12.2percent are of low level of education. The categories of highest formal education of the parent respondents range from WASSCE to $\mathrm{Ph} \mathrm{D}$. 31.6percent holds first degree, 15.5percent holds NCE certificates 13.4percent and 7.1percent are having master's degree and $\mathrm{Ph} \mathrm{D}$ degree respectively.

Table 2: Educational Qualification of Parent Respondents in Southwest Nigeria

\begin{tabular}{|l|c|c|}
\hline ITEM & Frequency & Percent \\
\hline EDUCATIONAL LEVEL & 584 & 87.8 \\
\hline HIGH LEVEL & 81 & 12.2 \\
LOW LEVEL & $\mathbf{6 6 5}$ & $\mathbf{1 0 0 . 0}$ \\
TOTAL & 81 & 12.2 \\
\hline CATEGORIES OF HIGHEST EDUCATIONAL QUALIFICATION & 31.6 \\
\hline WASC/SSCE SCHOOL CERT & 210 & 15.5 \\
FIRST DEGREE & 103 & 9.0 \\
NCE & 60 & 11.3 \\
OND & 75 & 13.4 \\
HND & 89 & 7.1 \\
MASTER'S DEGREE & 47 & 100.0 \\
PhD & 665 & \\
\hline Total & & \\
\hline
\end{tabular}




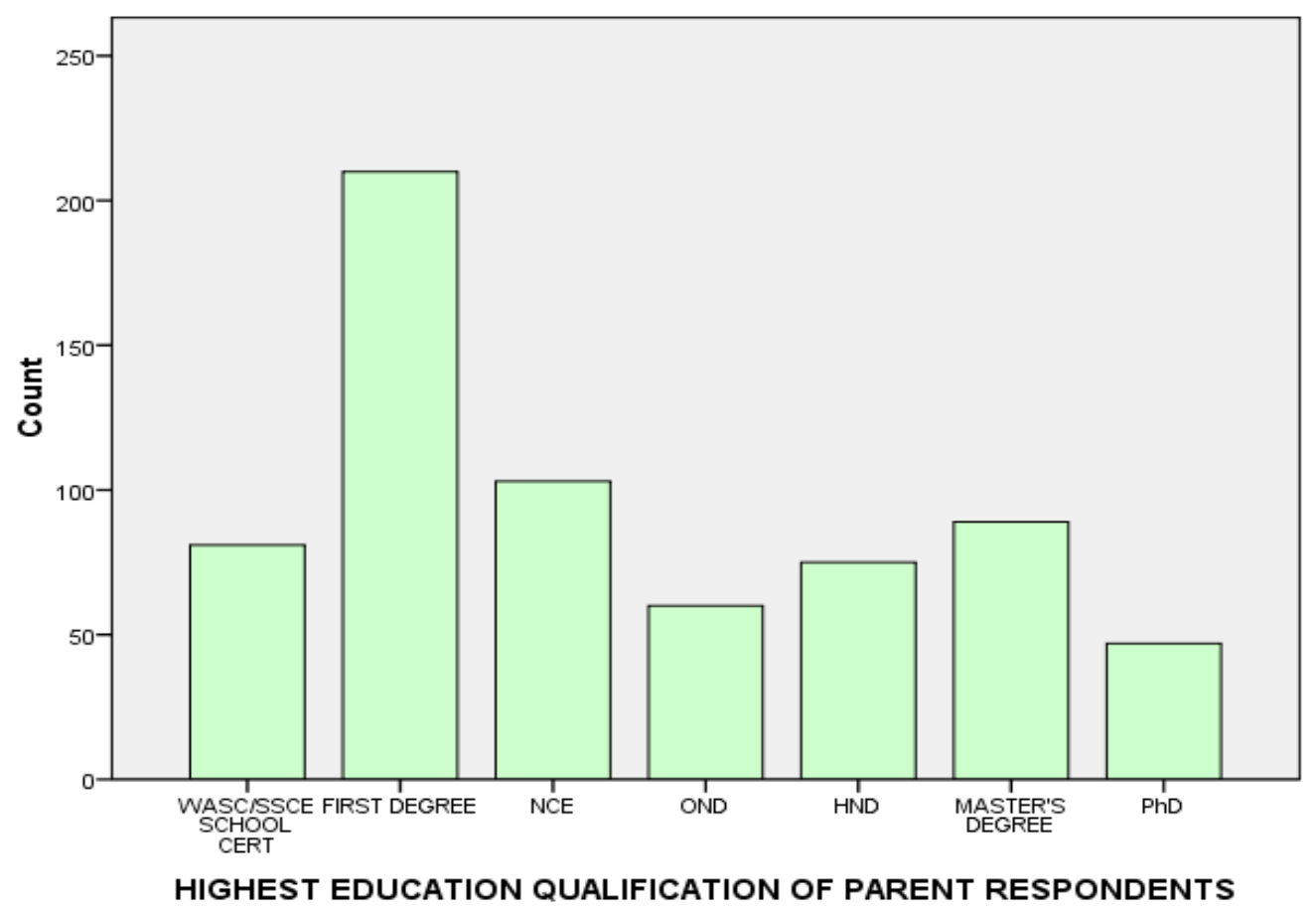

\section{OCCUPATION DISTRIBUTION OF PARENT RESPONDENTS IN SOUTHWEST NIGERIA}

An occupational characteristic of parent respondents in southwest Nigeria was examined in the course of this study and the results is presented in Table 3 and Figure 2 below. About 0.2percent each of the interviewed parents are unemployed, actresses, and administrative officers. Teaching profession ranked the highest number in terms of occupation engaged by parent. This is about 34 percent and is closely followed by civil servants (19.4percent); business men/women (12.5percent) and public servant with 9.6percent. 


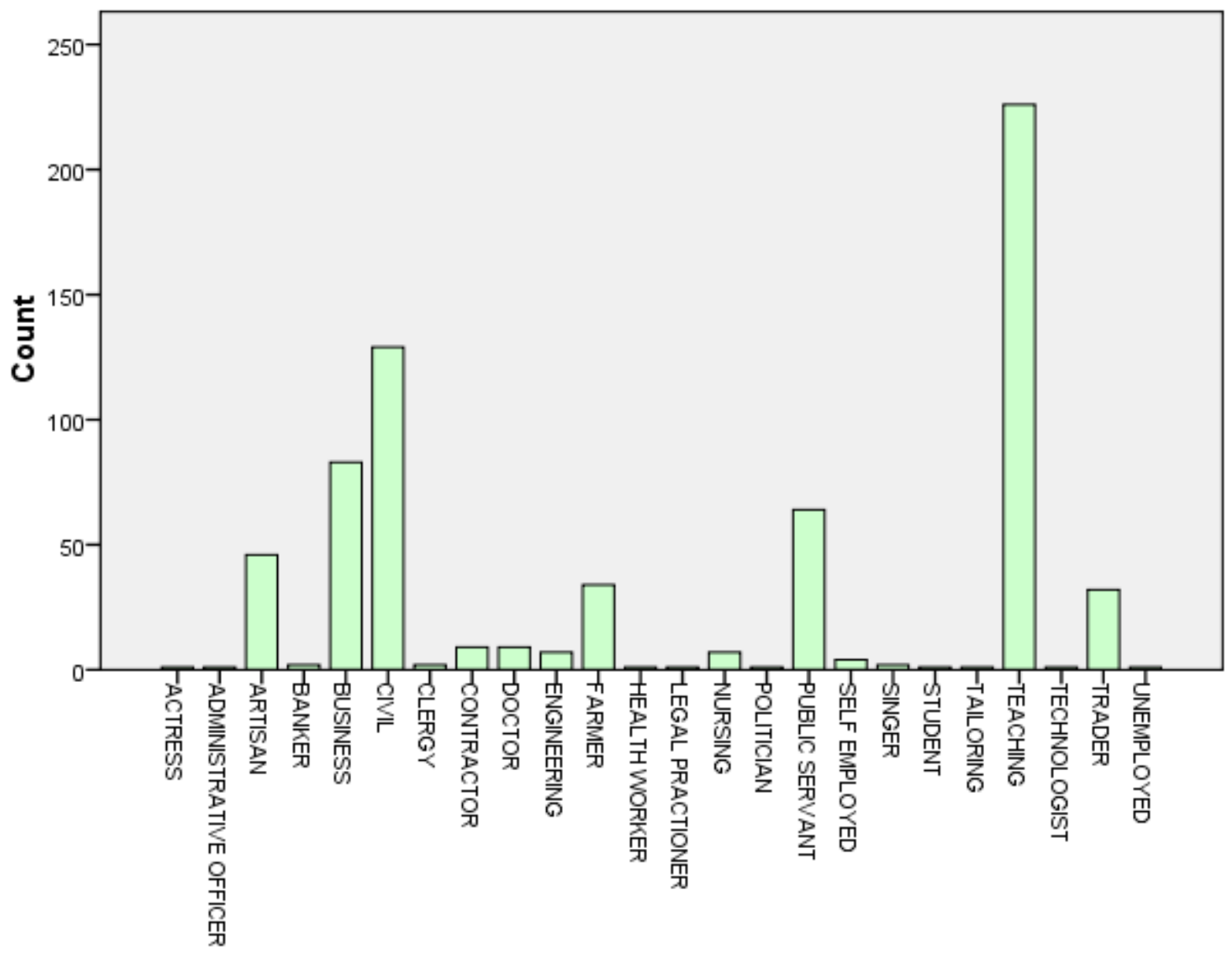

OCCUPATION OF PARENT RESPONDENTS

Occupation of parent respondents

\begin{tabular}{|l|r|r|}
\hline & Frequency & Percent \\
\hline ACTRESS & 1 & .2 \\
ADMINISTRATIVE OFFICER & 1 & .2 \\
ARTISAN & 46 & 6.9 \\
BANKER & 2 & .3 \\
BUSINESS & 83 & 12.5 \\
CIVIL & 129 & 19.4 \\
CLERGY & 2 & .3 \\
CONTRACTOR & 9 & 1.4 \\
DOCTOR & 9 & 1.4 \\
ENGINEERING & 7 & 1.1 \\
FARMER & 34 & 5.1 \\
HEALTH WORKER & 1 & .2 \\
LEGAL PRACTIONER & 1 & .2 \\
NURSING & 7 & 1.1 \\
POLITICIAN & 1 & .2 \\
PUBLIC SERVANT & 64 & 9.6 \\
SELF EMPLOYED & 4 & .6 \\
SINGER & 2 & .3 \\
STUDENT & 1 & .2 \\
TAILORING & 1 & .2
\end{tabular}




\begin{tabular}{|l|r|r} 
TEACHING & 226 \\
TECHNOLOGIST & 1 & 34.0 \\
TRADER & 32 & .2 \\
UNEMPLOYED & 1 & 4.8 \\
Total & 665 & .2 \\
\hline
\end{tabular}

\section{PARENT-CHILDREN LANGUAGE OF COMMUNICATION IN SOUTHWEST NIGERIA}

Table 4 and figure 4 below present the results of data collected on the most used language by parent respondents in communicating with their children at home. From the Table and figure, most parents (48 percent) use English language in communicating with their children while 35.8 percent use both English and Yoruba in communicating with their children. The remaining 15.6 percent use their indigenous language Yoruba in communication with their children. This results show that within the Yoruba speaking states of Nigeria most parents communicate with their wards in English language at the expense of their own indigenous language.

Table 4: Language Used Most By Parent In Communicating With Their Children In South West Nigeria

\begin{tabular}{|l|c|c|}
\hline LANGUAGE & FREQUENCY & PERCENT \\
\hline BOTH ENGLISH AND YORUBA & 238 & 35.8 \\
YORUBA & 104 & 15.6 \\
ENGLISH & 323 & 48.6 \\
\hline TOTAL & $\mathbf{6 6 5}$ & $\mathbf{1 0 0 . 0}$ \\
\hline
\end{tabular}

\section{FIG. 4: LANGUAGE USED MOST BY PARENT IN COMMUNICATING WITH THEIR CHILDREN IN SOUTH WEST NIGERIA}

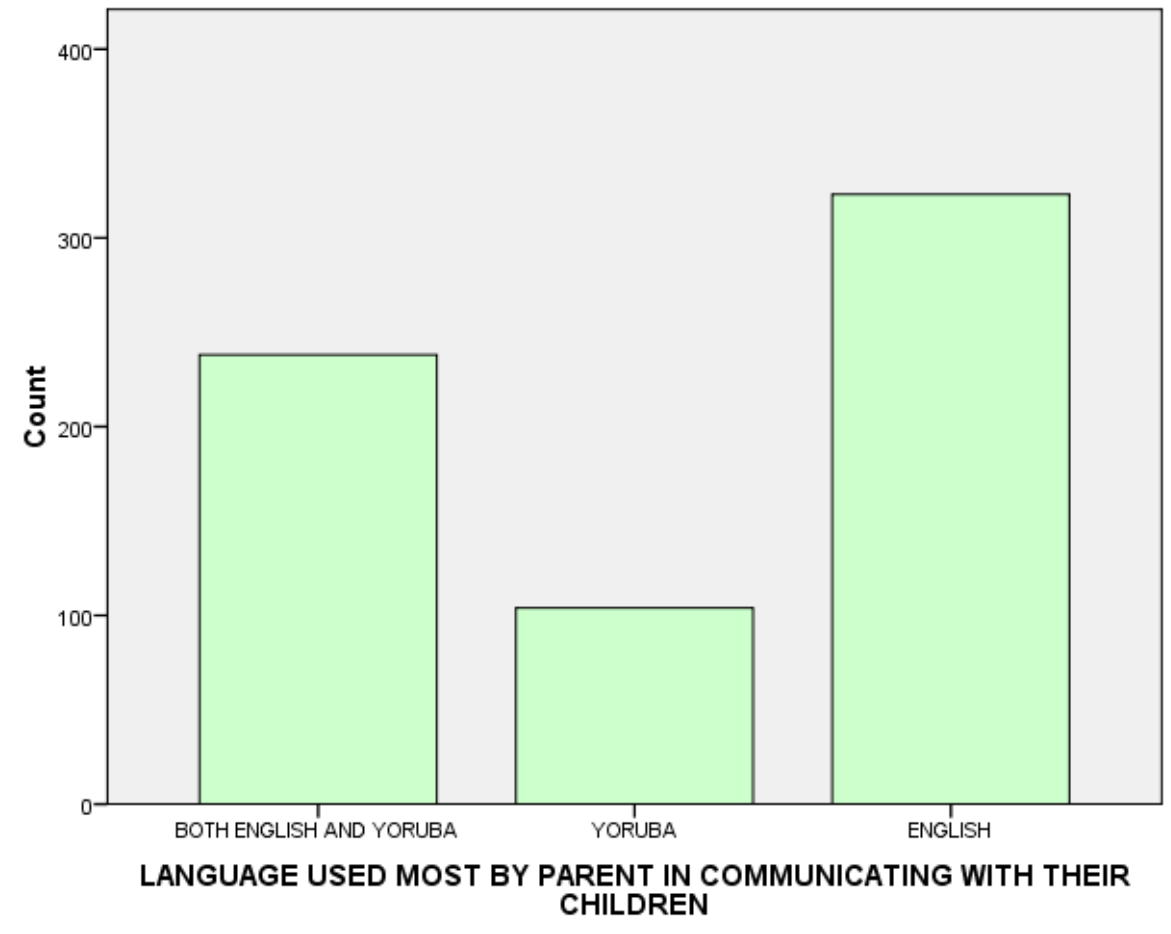

This study further used inferential statistics (Chi - square) to examine factors responsible for linguicide of indigenous languages in southwest Nigeria. The most used language of communication to their wards (children) was used as a proxy against parents' highest educational qualifications and the type of education engaged in by parents. The outcomes of these tests are presented in Tables 5 to 8 . 
Table 5: Cross tabulation Of Parent Respondents Highest Educational Qualification And The Most Used Language Of Communication To Their Children

Highest educational level of parent respondents against language used most by parent in communicating with their children

\begin{tabular}{|c|c|c|c|c|c|}
\hline & & \multicolumn{3}{|c|}{\begin{tabular}{|c|} 
LANGUAGE USED MOST BY PARENT IN \\
COMMUNICATING WITH THEIR CHILDREN
\end{tabular}} & \multirow[b]{2}{*}{ Total } \\
\hline & & $\begin{array}{c}\text { BOTH } \\
\text { YORUBA AND } \\
\text { ENGLISH } \\
\end{array}$ & YORUBA & ENGLISH & \\
\hline \multirow{7}{*}{$\begin{array}{l}\text { HIGHEST EDUCATIONAL } \\
\text { LEVEL OF PARENT } \\
\text { RESPONDENTS }\end{array}$} & $\begin{array}{l}\text { WASC/SSCE SCHOOL } \\
\text { CERT }\end{array}$ & $\begin{array}{c}22 \\
(27.16) \\
\end{array}$ & $\begin{array}{c}6 \\
(7.41) \\
\end{array}$ & $\begin{array}{c}53 \\
(65.43) \\
\end{array}$ & $\begin{array}{c}81 \\
(100.00) \\
\end{array}$ \\
\hline & FIRST DEGREE & $\begin{array}{c}63 \\
(30.00)\end{array}$ & $\begin{array}{c}45 \\
(21.43)\end{array}$ & $\begin{array}{c}102 \\
(48.57)\end{array}$ & $\begin{array}{c}210 \\
(100.00)\end{array}$ \\
\hline & $\mathrm{NCE}$ & $\begin{array}{c}19 \\
(18.45)\end{array}$ & $\begin{array}{c}14 \\
(13.59)\end{array}$ & $\begin{array}{c}70 \\
(67.96)\end{array}$ & $\begin{array}{c}103 \\
(100.00)\end{array}$ \\
\hline & OND & $\begin{array}{c}38 \\
(63.33) \\
\end{array}$ & $\begin{array}{c}6 \\
(10.00) \\
\end{array}$ & $\begin{array}{c}16 \\
(26.67) \\
\end{array}$ & $\begin{array}{c}60 \\
(100.00) \\
\end{array}$ \\
\hline & HND & $\begin{array}{c}37 \\
(49.33) \\
\end{array}$ & $\begin{array}{c}11 \\
(14.67) \\
\end{array}$ & $\begin{array}{c}27 \\
(36.00)\end{array}$ & $\begin{array}{c}75 \\
(100.00) \\
\end{array}$ \\
\hline & MASTER'S DEGREE & $\begin{array}{c}33 \\
(37.08) \\
\end{array}$ & $\begin{array}{c}13 \\
(14.61) \\
\end{array}$ & $\begin{array}{c}43 \\
(48.31) \\
\end{array}$ & $\begin{array}{c}89 \\
(100.00)\end{array}$ \\
\hline & $\mathrm{PhD}$ & $\begin{array}{c}12 \\
(25.53)\end{array}$ & $\begin{array}{c}9 \\
(19.15)\end{array}$ & $\begin{array}{c}26 \\
(55.32) \\
\end{array}$ & $\begin{array}{c}47 \\
(100.00) \\
\end{array}$ \\
\hline \multicolumn{2}{|c|}{ Total (ALL EDUCATIONAL LEVEL) } & $\begin{array}{c}238 \\
(28.87) \\
\end{array}$ & $\begin{array}{c}104 \\
(15.64) \\
\end{array}$ & $\begin{array}{c}323 \\
(55.49) \\
\end{array}$ & $\begin{array}{c}665 \\
(100.00) \\
\end{array}$ \\
\hline
\end{tabular}

\section{Note: Figures in brackets are percentages}

From Table 5 above, almost all categories of educational qualification of parent respondents except OND and HND holders used English language in communicating with their children at the expense of their indigenous language and this is followed by parents that used both their indigenous and English language in communication with their children. Furthermore, this study made use of Chi - square statistic $\left(X^{2}\right)$ to test whether there is a significant relationship between parent respondents education and linguicide of indigenous language. The result of the test is presented in Table 6.

Table 6: Chi - square Test of Relationship between Parent Respondents Educational Qualification and Most used language of communication with their Children

\begin{tabular}{|l|r|r|r|r|}
\hline \multicolumn{2}{|c|}{ Chi-Square Tests } & \\
\hline & & & & DECISION \\
& Value & $\begin{array}{c}\text { Degree of } \\
\text { freedom }\end{array}$ & $\begin{array}{c}\text { Level of } \\
\text { probability }\end{array}$ & \\
\hline Pearson Chi-Square & 70.122 & 12 & .000 & REJECT Ho \\
Likelihood Ratio & 70.450 & 12 & .000 & \\
N of Valid Cases & 665 & & & \\
\hline
\end{tabular}

Language transmission within a culture is expectedly to occur from generation to generation. It is observed based on the result in Table 6 that the more educated parents are the more they relegate their indigenous language and promote foreign language as the null hypothesis of no significant relationship between parent respondents' education qualification and linguicide of indigenous language (using language used in communicating with their children as proxy) was reject at $\mathrm{p}<0.05$ level of probability.

CROSS TABULATION OF PARENT RESPONDENTS' REASON(S) FOR THE LANGUAGE CHOICE OF COMMUNICATION AND MOST USED LANGUAGE IN COMMUNICATING WITH THEIR CHILDREN

Table 7: Cross tabulation Of Parent Reason For Preference Of Language Choice Of Communication And Language Used Most By Parent In Communicating With Their Children 


\begin{tabular}{|l|c|c|c|c|}
\hline & \multicolumn{2}{|c|}{$\begin{array}{c}\text { LANGUAGE USED MOST BY PARENT } \\
\text { IN COMMUNICATING WITH THEIR }\end{array}$} & \multirow{2}{*}{ CHILDREN } \\
\cline { 1 - 4 } & $\begin{array}{c}\text { BOTH } \\
\text { YORUBA AND } \\
\text { ENGLISH }\end{array}$ & YORUBA & ENGLISH & TOTAL \\
\hline $\begin{array}{l}\text { PARENT REASON FOR PREFERENCE OF } \\
\text { LANGUAGE CHOICE OF COMMUNICATION }\end{array}$ & & & & \\
\hline $\begin{array}{l}\text { CHILDREN EARLY IMBIBE COMMONLY } \\
\text { SPOKEN LANG }\end{array}$ & 8 & 5 & 10 & 23 \\
\hline CHILDREN PREFER IT & 1 & 0 & 0 & 1 \\
\hline COMPETENCY & 27 & 0 & 38 & 65 \\
\hline DON'T WANT YORUBA LANG TO DIE & 0 & 0 & 1 & 1 \\
\hline $\begin{array}{l}\text { EASE OF COMMUNICATION IN BOTH } \\
\text { LANGUAGES }\end{array}$ & 96 & 0 & 0 & 96 \\
\hline GENERALLY ACCEPTED & 4 & 0 & 64 & 68 \\
\hline LINGUAL FRANCA & 3 & 0 & 120 & 123 \\
\hline MY LANGUAGE & 0 & 38 & 0 & 38 \\
\hline PROMOTE CULTURE & 0 & 33 & 0 & 33 \\
\hline SCHOOL ADOPTED LANG & 5 & 0 & 41 & 46 \\
\hline $\begin{array}{l}\text { STANDOUT WHERE THEY FOUND } \\
\text { THEMSELVES }\end{array}$ & 1 & 0 & 0 & 1 \\
\hline TO BUILD THEM TO BE VOCAL AND SOUND & 4 & 0 & 1 & 5 \\
\hline TO EDUCATE THEM & 1 & 0 & 0 & 1 \\
\hline WANT THEM UNDERSTAND IT & $\mathbf{2 3 8}$ & $\mathbf{1 0 4}$ & $\mathbf{3 2 3}$ & $\mathbf{6 6 5}$ \\
\hline TOTAL & & & & \\
\hline
\end{tabular}

Table 7 above presents a cross tabulation of reasons parent respondents put forward to using the language for communicating with their children at home. From the table, only 104 respondents use purely Yoruba language an indigenous language to communicate with their children at home while 238 and 323 parent respondents use both English and Yoruba and English language respectively in communicating with their children. The frequency distributions of reasons given by those parents that use purely Yoruba language are children early imbibe spoken language (5); my language (38); and to promote culture (38). This result uniquely portrays factors that can keep a language alive from generation to generation. On the other hand reasons given by those parents who sue both English and Yoruba in communicating with their children are mostly: competency (27); ease of communication in both languages (96) and intention for the children to understand both languages (88). Parent respondents' reasons given mostly include: lingual Franca (120); generally acceptability (64); schools adopt English language (41); and want them to understand it (48). This group of parent is relatively large in the study area and is typically having a bias mind set against indigenous language.

\section{SCHOOL DATA}

\section{Category of School Used As Target Group}

The category of schools used in the study is both private and Government schools across primary and secondary school educational system. 50.8 percent of the school is private while the remaining 49.2 percent of the schools are public schools. There is a fairly balance in the category of schools used

Table8: Category Of School Used As Target Group

\begin{tabular}{|ll|r|r|}
\hline & \multicolumn{1}{|c|}{ Frequency } & \multicolumn{1}{|c|}{ Percent } \\
\hline Valid & PRIVATE & 61 & 50.8 \\
& PUBLIC & 59 & 49.2 \\
& Total & 120 & 100.0 \\
\hline
\end{tabular}

Distribution Of Schools By Use Of Yoruba As A medium Of Communication

Table 9 presents distribution of school respondents by use of Yoruba language as a medium of communication. From the Table, 55.8 percent of schools in the study area do not use Yoruba language as a medium of communication. This can probably denote 
that communication in Yoruba language is not allowed in 55.8percent of schools in southwest Nigeria while the remaining 44.2 percent use Yoruba language as means of communication.

TABLE9: Distribution Of Schools By Use Of Yoruba Language As A Means Of Communication

\begin{tabular}{|l|c|c|}
\hline & Frequency & Percent \\
\hline NO & 67 & 55.8 \\
YES & 53 & 44.2 \\
\hline Total & $\mathbf{1 2 0}$ & $\mathbf{1 0 0 . 0}$ \\
\hline
\end{tabular}

\section{DISTRIBUTION OF SCHOOL BY CLASS TYPES WHERE YORUBA LANGUAGE IS USED AS A MEDIUM OF COMMUNICATION}

Table 10 reveals the distribution of schools by class type where Yoruba language is used as a means of communication. From the Table, Yoruba language is made use of in Basic schools which covers Basic 1 - 9 (33.3percent) and 11.7 percent of senior secondary class of the schools used in this study use Yoruba language

TABLE 10: Distribution of School by Class Type Where Yoruba Language Is Used As A Medium Of Communication

\begin{tabular}{|l|r|r|}
\hline & Frequency & Percent \\
\hline ALL CLASSES & 1 & .8 \\
BASIC SCH & 2 & 1.7 \\
JUNIOR SCHOOL & 40 & 33.3 \\
NO & 4 & 3.3 \\
NONE & 1 & .8 \\
SENIOR SCH & 58 & 48.3 \\
\hline Total & 14 & 11.7 \\
\hline
\end{tabular}

Distribution of Schools by Teaching of Yoruba In Schools

Distribution of schools used in this study by teaching of Yoruba in schools is presented in Table 11 below. From the Table, teaching of Yoruba is observed in 53.3percent of the school, while the remaining 46.7percent do not teach Yoruba.

TABLE11: Distribution Of Schools By Teaching Of Yoruba In Schools

\begin{tabular}{|l|r|r|}
\hline & Frequency & \multicolumn{2}{|c|}{ Percent } \\
\hline NO & 56 & 46.7 \\
YES & 64 & 53.3 \\
\hline Total & 120 & 100.0 \\
\hline
\end{tabular}

\section{Cross Tabulation Of Schools Teaching Yoruba And Reasons Given For Teaching/Not Teaching Yoruba}

This study examines the reason(s) for teaching/not teaching Yoruba in schools in the study area. The result is presented in Table 12 below. Similar to result in Table11, 64 schools teach Yoruba and the reasons for teaching the language are presented in cross tabulation Table in Table12. The reasons given include: syllabus requirement (34); indigenous language (16); continuity of language (3) and to allow the students speak the language (3). The remaining 56 schools out of 120 schools used for this study do not teach Yoruba in their schools the reasons provided for none teaching of Yoruba include: unavailability of Yoruba teacher (37); parents prefer use of English (4); poor general acceptability of Yoruba (9).

TABLE 12: CROSS TABULATION OF SCHOOLS TEACHING YORUBA AND REASONS GIVEN FOR TEACHING/NOT TEACHING YORUBA

\begin{tabular}{|l|c|c|c|}
\hline & \multicolumn{2}{|c|}{ SCHOOL TEACH YORUBA } & \multirow{2}{*}{ Total } \\
\hline REASON GIVEN & NO & YES & \multirow{2}{*}{3} \\
\hline CONTINUITY OF LANGUAGE & 0 & 3 & 2 \\
\hline CORE SUBJECT & 0 & 2 & 2 \\
\hline
\end{tabular}




\begin{tabular}{|l|c|c|c|}
\hline GOVERNMENT APPROVED & 0 & 2 & 2 \\
\hline INDIGENOUS LANGUAGE & 0 & 16 & 16 \\
\hline IS NOT GENERALLY ACCEPTABLE & 9 & 0 & 9 \\
\hline NEEDED IN FUTURE & 2 & 4 & 6 \\
\hline NO REASON & 4 & 0 & 4 \\
\hline NO YORUBA TEACHER & 37 & 0 & 37 \\
\hline PARENTS PREFER USE OF ENGLISH & 4 & 0 & 4 \\
\hline PART OF SYLABUS & 0 & 34 & 34 \\
\hline TO SPEAK NATIVE LANG & 0 & 3 & 3 \\
\hline Total & $\mathbf{5 6}$ & $\mathbf{6 4}$ & $\mathbf{1 2 0}$ \\
\hline
\end{tabular}

\section{YOUTH DATA}

\section{DISTRIBUTION OF YOUTH RESPONDENTS BY HIGHEST EDUCATIONAL QUALIFICATION}

Table 13 and Figure 6 present the distribution of youth respondent by their highest educational qualification attained. From the Table and Figure presented, most of the youth interviewed had WASC/WASSCE certificate while the least of them hold OND certificate. This results show that the youth can read and write and thereby understand what is asked of them.

Table 13: Distribution of Youth Respondents by Highest Educational Level

\begin{tabular}{|l|c|c|}
\hline & Frequency & Percent \\
\hline PRIMARY SCHOOL CERTIFICATE & 29 & 24.2 \\
WAEC/SSCE SCHOOL CERTIFICATE & 44 & 36.7 \\
FIRST DEGREE & 12 & 10.0 \\
NCE & 11 & 9.2 \\
OND & 7 & 5.8 \\
HND & 17 & 14.2 \\
\hline Total & $\mathbf{1 2 0}$ & $\mathbf{1 0 0 . 0}$ \\
\hline
\end{tabular}




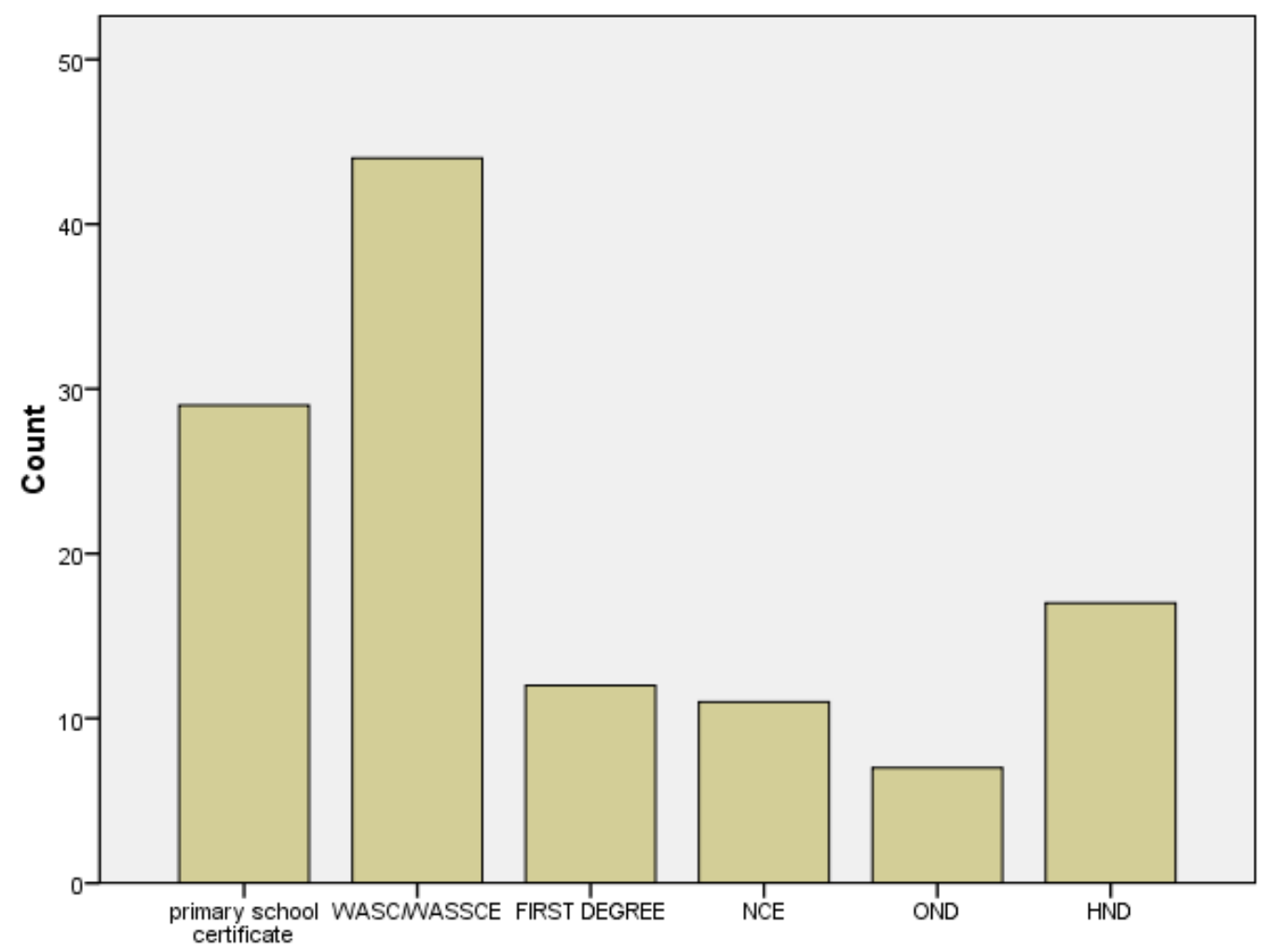

HIGHEST EDUCATIONAL LEVEL OF YOUTH RESPONDENTS

\section{AGE DISTRIBUTION OF YOUTH RESPONDENTS}

The age distribution of the youth respondents used in this study is presented in Table 14 and Figure 7. The pictorial representation as well as frequency distribution of their age show that most of the youth in the study area is within age bracket of 10 and 20 years while the least of them (13percent) is within the age bracket of 31 and 35 years. The remaining 39.2percent falls within the age bracket of 21 and 30 years. This result confirms the youthfulness of the respondents.

Table 14: Distribution of Youth Respondent by Age

\begin{tabular}{|l|c|c|}
\hline & Frequency & Percent \\
\hline BETWEEN 10 - 20 YEARS & 60 & 50.0 \\
BETWEEN 21 - 30 YEARS & 47 & 39.2 \\
BETWEEN 31 - 35 YEARS & 13 & 10.8 \\
\hline Total & $\mathbf{1 2 0}$ & $\mathbf{1 0 0 . 0}$ \\
\hline
\end{tabular}




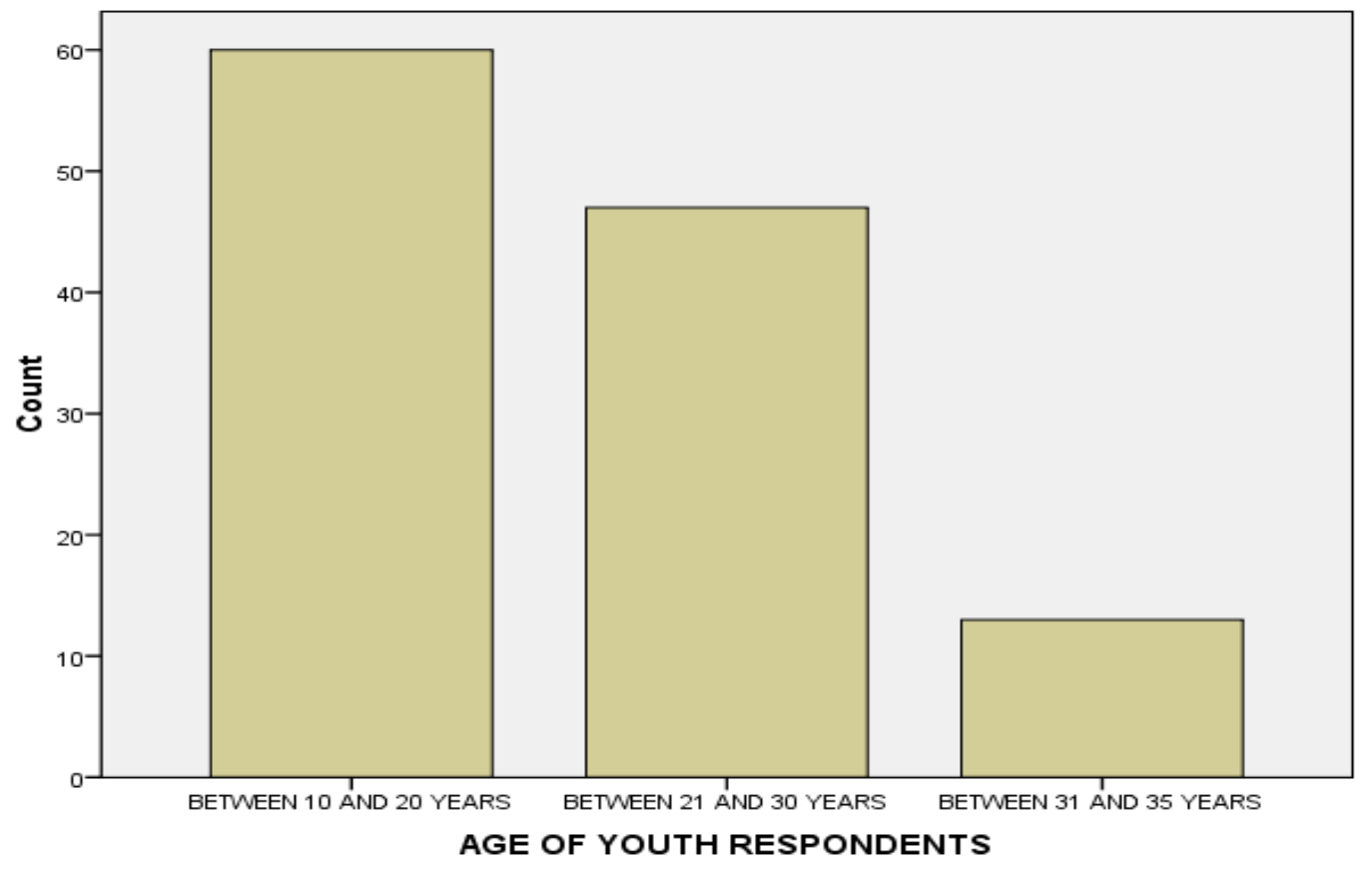

\section{YOUTH RESPODENTS RESPONSES TO QUESTION BOTHERING INDIGENOUS LANGUAGE}

This section present result of analyzed data relating to youth view and link with indigenous language.

\section{DISTRIBUTION OF YOUTH BY LANGUAGE USED BY THEIR PARENTS IN COMMUNICATION WITH THEM}

The result in Table 15 shows the distribution of youth respondents by the language used most in communicating with them at home. The result reveals that English language is predominantly used and the result is similar to what was admitted by parents in the study area (see Table 4)

Table 15: Distribution of youth by Language used by their Parents in Communication with Them

\begin{tabular}{|l|c|c|}
\hline & Frequency & Percent \\
\hline ENGLISH & 95 & 13.3 \\
NATIVE NON YORUBA & 9 & 7.5 \\
YORUBA & 16 & 79.2 \\
\hline Total & $\mathbf{1 2 0}$ & $\mathbf{1 0 0 . 0}$ \\
\hline
\end{tabular}

\section{DISTRIBUTION OF YOUTH RESPONDENTS BY LANGUAGE OF COMMUNICATION WITH THEIR FRIENDS}

Table 16 reveals the distribution of youth respondents by the language of communication with their peers. From the result, 72.5percent of the youth use indigenous language (71.7\% use Yoruba language, $0.8 \%$ use native non - Yoruba language) to communicate with their peer group which is in contrast with the language adopted by their parent in communication with them. 23.3percent used English language while 4.2percent use both English and Yoruba.

Table 16: Distribution of Youth Respondents by Language of Communication with Their Friends

\begin{tabular}{|l|c|c|}
\hline & Frequency & Percent \\
\hline BOTH & 5 & 4.2 \\
ENGLISH & 28 & 23.3 \\
NATIVE NON YORUBA & 1 & .8 \\
YORUBA & 86 & 71.7 \\
\hline Total & $\mathbf{1 2 0}$ & $\mathbf{1 0 0 . 0}$ \\
\hline
\end{tabular}




\section{DISTRIBUTION OF YOUTH RESPONDENTS BY EASIEST LANGUAGE OF EXPRESSION}

This study examined the easiest language of expression of self by youth respondents and the result of the finding is presented in Table 17 below. From the Table, 55.8percent find it very easy and convenient to express themselves using Yoruba language while 2.5percent love native language for their expression. 40percent find English as being easiest language to express themselves conveniently. The remaining 1.7percent is comfortable with both English and indigenous language to express themselves.

Table 17: Distribution of Youth Respondents by Easiest Language Of Expression

\begin{tabular}{|l|c|c|}
\hline & Frequency & Percent \\
\hline BOTH & 2 & 1.7 \\
ENGLISH & 48 & 40.0 \\
NATIVE LANGUAGE & 3 & 2.5 \\
YORUBA & 67 & 55.8 \\
\hline Total & $\mathbf{1 2 0}$ & $\mathbf{1 0 0 . 0}$ \\
\hline
\end{tabular}

\section{DISTRIBUTION OF YOUTH RESPONDENTS BY LANGUAGE SPOKEN IN DREAMS}

The main language spoken in the dreams by youth respondents was asked as it is a common thing to get involved in conversation in physical and metaphysical with most spoken language. The result of the finding among the youth respondents is presented in Table 18. From the Table same percent of youth respondent (43.3percent) speak Yoruba and English language in their dream while 6.7percent have no clue of what language they speak in their dreams. The remaining 4.2 percent and 2.5 percent speak both language and other native language respectively in their dream.

Table 18: Distribution of Youth Respondents by Language Spoken In Dreams

\begin{tabular}{|l|c|c|}
\hline & Frequency & Percent \\
\hline BOTH & 5 & 4.2 \\
ENGLISH & 52 & 43.3 \\
NATIVE LANGUAGE & 3 & 2.5 \\
NO IDEA & 8 & 6.7 \\
YORUBA & 52 & 43.3 \\
\hline Total & $\mathbf{1 2 0}$ & $\mathbf{1 0 0 . 0}$ \\
\hline
\end{tabular}

\section{CONCLUSION}

This study examined imminent linguicide of indigenous language in Southwest Nigeria which is predominantly Yoruba speaking geo - political zone of Nigeria using 720parent, 120 schools and 120 youths as respondent sample size randomly selected from all the six states in the zone. Only 665 parent respondents, 120 schools and 120 youths were finally used for the study. The analyzed results show that parents and schools in the zone have greatly contributed to the gradual loss of indigenous language in the zone. Factors of educational background, occupation of the parents were found to be statistically significant as there is a strong relationship between these factors and linguicide of indigenous language. Many of the parents most preferred to communicate with their children using English language and reasons given range from the English language being generally acceptable, lingual franca and for the development of their children, all at the detriment of their own indigenous language. This act not vividly realized is a pointer to loss of Yoruba language and if not immediately curbed, will lead to loss of identity among future generation.

The schools on their part that are supposedly expected to transmit culture have gone contrary to government policy which mandatorily allows the use of indigenous language at basic education level. The culprits are mostly the private schools. The reason given is tied to parents' demand of use of English language. However, youths with average age of 21 and 30 years, were not found to contribute to linguicide of indigenous language as the result shows that they predominantly use indigenous language to communicate with their peers, their thoughts are expressed mostly in indigenous language. However, if the parents who have great influence on their children prefer English language or combination of English language and Yoruba within shortest time the youth will concur and adopt English as the school equally stressed the use of English language. 
Parents should be educated on the importance of indigenous languages in the lives of children. They should be made to see the danger inherent in the loss of one's indigenous language. This could be done via jingles on radio and television. Awareness rallies could also be organized in public places like markets and motor parks. Also, lectures could be organized in order to call the attention of parents to the menace of the waning spoken Yoruba language.

\section{REFERENCES}

Aladesote, O.I., Johnson. O.V., Agbelusi, O., James, C. (2016) Selection of Factors Responsible for Yoruba Language Extinction Using Feature Extraction Techniques. In Pyrex Journal of Educational Research and Reviews. Vol 2(1) pp001005. Http://www.pyrexjournal.org/pjerr

Babalola, E.T., Onanuga, P.A. (2012) Athrophization of Minority Languages: Indigenousa Folktales to the Rescue. In International Journal and Linguistics. Vol 14, No 1. ISSN 1948-5425

Balogun, T.A. (2013) An Endangerment Nigerian Indigenous Language. In African Nebula. Issue 6, 2013

Glavin, Mayowa, Montenegro, Terry (2008) “In Defence of Difference” Seed Magazine, $7^{\text {th }}$ October, 2008

Olaoye, A. A. (2014) Sociolinguist's Documentation of Endangered Ethnography of Communication in Yoruba Language. In World Journal of English Language. http://dx.doi.org/10.5430/wjel.v4nlp32

Oshodi, B (2013) An Assessment of Indigenous Languages and Factors of Language Endangerment: Can the Indigenous Languages Survive? In Dialectologia 13, pp 1-25, ISSN 2013-2247.

Owolabi, K (2007) Ó tó gẹé, Omo Odùduwà. Ogun İsàmúlò Èdè Yorùbá ní Ibikíbi, ní Ipòkípò, àti ní Àyèkáyè Di Jijjà Wàyí.

Nigeria: Universal Akada Books (Nig) Ltd

\section{BIOGRAPHY}

Dr Aderibigbe, Moronmubo Martina has been teaching Yoruba for almost 3 decades. She is a teacher of teachers as she teaches in a teacher training College. Her first degree (B.A.) Yoruba in 1989 was from University of Ilorin, Ilorin, Nigeria, while she bagged her Master's Degree (M.A.) Yoruba Literature in 2006, and PhD Yoruba Literature in 2013 both from University of Ibadan, Ibadan, Nigeria. She has to her credit solely or jointly authored Yoruba books and many journal publications. She has attended over fifty conferences in many countries including Germany, United States of America and many parts of Nigeria. Presently, she is a Chief Lecturer in the Department of Yoruba, Federal College of Education, Abeokuta, Nigeria. 